\title{
THE EFFECT OF MEDIA VISUAL IN THREE DIMENSIONS TOWARDS THE RESULT OF MATH LEARNING AT ELEMENTARY SCHOOL
}

\author{
Muhammad Fendrik \\ PGSD FKIP Universitas Riau \\ muhammad.fendrik@lecturer.unri.ac.id
}

\begin{abstract}
This research is a quasi experimental with non equivalent control group design based on how low students mathematics scores. The purpose of this research is to know the difference of the mathematics scores of students who learn by using three dimensional visual media with those who learn using two dimensional visual media. This research was executed in Muhammadiyah 6 elementary school Pekanbaru on the even semester of 2016/2017 study year. Subjects of this research were Muhammadiyah 6 elementary school 4th grade students with IVA students as control class and IVB students as experimental class. Early step of this research is by giving pretest to the control and experimental class. The next step is applying study methods using three dimensional visual media to experimental class and two dimensional visual media to control class. The last step is giving post test to control and experimental classes. Result of this research shows that there is a difference of significant increase of study results with 0.05 significant quality shown by average score of pretest taken by experiment class of only 54,96 increasing to 79,13 average scores of post test. With average gain of 0.54 (considered medium category). Meanwhile, control class average scores of pretest of 55, 67 only increasing to 64,33 on the post test, with the average gain of 0.05 (considered low category).
\end{abstract}

Keywords: Three Dimensional Visual Media, Mathematics Study Scores, Elementary School

\begin{abstract}
ABSTRAK
Penelitian ini merupakan penelitian eksperimen semu dengan desain non equivalent control group designs yang dilatarbelakangi oleh rendahnya hasil belajar matematika siswa. Penelitian ini bertujuan untuk mengetahui perbedaan hasil belajar matematika siswa antara siswa yang memperoleh pembelajaran menggunakan media visual tiga dimensi dengan siswa yang memperoleh pembelajaran dengan media dua dimensi. Penelitian ini dilaksanakan di SD Muhammadiyah 6 Pekanbaru pada semester genap tahun pelajaran 2016/2017. Subjek penelitian adalah siswa kelas IV di SD Muhammadiyah 6 Pekanbaru dengan siswa kelas IVA sebagai kelas kontrol dan kelas IVB sebagai kelas eksperimen. Tahapan awal pada penelitian ini adalah memberikan tes awal terhadap kelas kontrol dan eksperimen, selanjutnya menerapkan pembelajaran dengan menggunakan media visual tiga dimensi pada kelas eksperimen dan media visual dua dimensi pada kelas kontrol. Langkah terakhir yaitu memberikan tes akhir pada kelas kontrol dan eksperimen. Hasil penelitian menunjukkan bahwa
\end{abstract}


terdapat perbedaan peningkatan hasil belajar yang signifikan dengan taraf signifikan 0,05 yang ditunjukkan dari rata-rata tes awal (pretest) kelas eksperimen 54,96 menjadi 79,13 pada tes akhir (postest) dengan rata-rata peningkatan (gain) 0,54 (termasuk kategori sedang). Sedangkan kelas kontrol memiliki peningkatan rata-rata tes awal (pretest) dari 55,67 menjadi 64,33 pada tes akhir (postest) dengan rata-rata peningkatan (gain) 0,05 (termasuk kategori rendah).

Kata Kunci: Media Visual Tiga Dimensi, Hasil Belajar Matematika, Sekolah Dasar

\section{A. PENDAHULUAN}

Pendidikan di sekolah berfungsi untuk mentransfer ilmu pengetahuan agar anak didik mampu menyelesaikan berbagai macam permasalahan yang mesti diberi solusi seiring dengan perkembangan ilmu pengetahuan dan teknologi. Salah satu mata pelajaran yang mendukung perkembangan ilmu pengetahuan dan teknologi adalah matematika.

"Undang-Undang tentang Sistem Pendidikan Nasional No. 20 tahun 2003 menyatakan bahwa pendidikan adalah usaha sadar dan terencana untuk mewujudkan suasana belajar dan proses pembelajaran agar peserta didik secara aktif mengembangkan potensi dirinya untuk memiliki kekuatan spritual keagamaan pengendalian diri, kepribadian, kecerdasan, akhlak mulia, serta keterampilan yang diperlukan dirinya, masyarakat, bangsa dan negara".

Survei dari PISA (Program for International Student Assassment) tahun 2015 mengenai kemampuan matematika, membaca, dan sains menunjukkan bahwa Indonesia menduduki peringkat 69 dari 76 negara. Selain itu, hasil studi TIMSS (Trends in International Mathematics and Science Study) pada kemampuan matematika berada diperingkat 45 dari 50 negara. Dari kedua survei tersebut dapat disimpulkan bahwa prestasi siswa Indonesia dibidang matematika masih rendah.

Hal tersebut sejalan dengan hasil yang didapatkan saat melakukan observasi di SD Muhammadiyah 6 Pekanbaru, terdapat banyak siswa yang mengalami kesulitan dalam menyelesaikan soal-soal yang telah diberikan oleh guru. Faktor penyebab permasalahan tersebut diantaranya berasal dari guru yaitu kurang bervariasinya strategi pembelajaran yang digunakan sehingga kurang menarik perhatian siswa untuk tetap fokus pada proses pembelajaran yang berlangsung. Hal itu berdampak pada hasil belajar yang jauh dari hasil yang diharapkan. Untuk itu, perlu adanya upaya guru dalam proses 
pembelajaran yaitu salah satunya dengan menggunakan media pembelajaran.

Hal ini berdampak pada hasil belajar dari yang diharapkan. Untuk itu, perlu adanya upaya guru dalam memperbaiki proses pembelajaran, yaitu salah satunya dengan menggunakan media pembelajaran. Media pembelajaran ini merupakan salah satu komponen penting yang mempengaruhi keberhasilan belajar siswa. Pernyataan ini sejalan dengan pendapat Mudjiono dalam Sundayana (2015: 25) yang menyatakan bahwa dalam proses belajar mengajar ada empat komponen penting yang mempengaruhi keberhasilan belajar siswa, yaitu: 1) bahan belajar; 2) suasana belajar; 3) media dan sumber belajar; serta 4) guru sebagai subyek pembelajaran.

\section{Pengoptimalan}

keempat komponen tersebut sangatlah penting dalam mencapai tujuan pembelajaran yang diharapkan. Sebagaimana pendapat Usman dalam Fendrik (2015: 82) yang mengatakan bahwa pembelajaran matematika tidak hanya mengembangkan aspek kognitif saja, melainkan juga pada aspek afektif, karena dalam proses pembelajaran guru juga dituntut untuk terus mengembangkan nilai-nilai kehidupan. Sehingga media yang digunakan dalam proses pembelajaran dapat dipahami dan digunakan siswa dalam kehidupan sehari-hari.

Salah satu media yang cocok yaitu media visual, menurut Levie \& Lentz dalam Arsyad (2016: 20-21) mengemukakan fungsi media visual yang salah satunya yaitu fungsi kognitif yang terlihat dari temuantemuan penelitian yang mengungkapkan bahwa lambang visual atau gambar memperlancar pencapaian tujuan untuk memahami dan mengingat informasi atau pesan yang terkandung dalam gambar. Hal ini menunjukkan bahwa media visual dapat digunakan untuk memperjelas informasi dalam pembelajaran matematika sehingga dapat meningkatkan hasil belajar matematika. Media visual yang menarik dapat membuat siswa fokus dalam memperhatikan guru dalam menyampaikan informasi/ pesan.

Adapun rumusan masalah dalam penelitian ini adalah "Apakah terdapat perbedaan hasil belajar matematika antara siswa yang memperoleh pembelajaran menggunakan media 
visual tiga dimensi dengan siswa yang memperoleh pembelajaran dengan media dua dimensi?". Secara umum penelitian ini bertujuan untuk mengetahui seberapa besar pengaruh media visual terhadap hasil belajar matematika siswa sekolah dasar dan secara khusus penelitian ini bertujuan untuk mengetahui perbedaan hasil belajar matematika siswa yang memperoleh pembelajaran menggunakan media visual tiga dimensi dengan siswa yang memperoleh pembelajaran dengan media dua dimensi.

Manfaat penelitian merupakan dampak dari pencapaiannya tujuan. Penelitian ini diharapkan dapat memberikan banyak manfaat dan lebih komprehensif terhadap peneliti khususnya, serta pada umumnya bagi instansi-instansi pendidikan yang sedang atau akan mengembangkan penggunaan media visual tiga dimensi. Secara idealnya penelitian ini diharapkan dapat bermanfaat bagi beberapa aspek, diantaranya:

1. Secara Teoritis, yaitu memberikan sumbangan keilmuan terhadap perkembangan ilmu pengetahuan terutama berkenaan dengan media visual tiga dimensi siswa sekolah dasar dan sebagai bahan referensi bagi peneliti-peneliti lain yang akan melakukan penelitian yang serupa pada masa yang akan datang.

2. Secara Praktis, penelitian ini diharapkan dapat memberi sumbangan pemikiran dalam pembelajaran matematika di sekolah dasar dan secara khusus diharapkan bermanfaat bagi berbagai pihak, diantaranya:

a. Bagi institusi yang diteliti, sebagai masukan yang konstruktif dalam media visual tiga dimensi.

b. Menjadi bahan masukan sekaligus referensi bagi kepala sekolah, guru, komite sekolah dan seluruh warga sekolah dalam memahami dan menggunakan media visual tiga dimensi.

c. Bagi siswa, melalui penelitian ini diharapkan dapat menggunakan media visual tiga dimensi dalam setiap pembelajaran matematika.

\section{B. LANDASAN TEORI}

\section{Media Visual Tiga Dimensi}

Menurut Rima (2016: 21) media visual merupakan media yang memiliki unsur utama berupa garis, bentuk, warna, dan tekstur dalam penyajiannya. Ditambahkan Sanjaya 
(2011: 211) media visual yaitu media yang dapat dilihat saja tidak mengandung suara. Selanjutnya menurut Mumtahanah (2014: 94) Media visual adalah media yang hanya mengandalkan indera penglihatan, seperti film strip, slide, film bisu, foto/ gambar, grafik, globe/ peta, chart/ bagan, diagram, OHP, dan lain-lain. Dapat dijelaskan bahwa media visual adalah semua alat yang digunakan dalam proses pembelajaran yang hanya bisa dilihat baik dalam bentuk dua dimensi maupun tiga dimensi guna meningkatkan pemahaman siswa terhadap materi yang diajarkan serta memperkuat ingatan akan isi materi pelajaran.

Media pembelajaran sebagai alat/ sarana penghubung untuk mencapai pesan yang harus dicapai oleh siswa dalam kegiatan proses pembelajaran. Hal ini dikarenakan dalam pembelajaran matematika erat kaitannya dengan konteks kehidupan nyata. Dengan demikian, guru harus mampu mentransfer

dan mengembangkan pengetahuan dengan menggunakan media pembelajaran agar materi yang diajarkan kepada siswa dapat diterima dengan mudah dan tujuan pembelajaran dapat tercapai. Adapun media yang dimaksud disini adalah media visual tiga dimensi.

Menurut Ryandra Ashar dalam Asrotun (2014: 16) media tiga dimensi memiliki arti sebuah media yang ditampilkannya dapat diamati dari arah pandang mana saja dan mempunyai dimensi panjang, lebar dan tinggi. Pendapat lain dikemukakan oleh Susilana dan Riyana (2009: 23) yang memaparkan bahwa media tiga dimensi dapat dibagi menjadi dua kelompok, yaitu media objek sebenarnya dan media objek pengganti. Sedangkan media sebenarnya dibagi menjadi dua jenis yaitu, media objek alami dan media objek buatan. Media objek alami dapat dibagi ke dalam dua jenis, yaitu objek alami yang hidup dan objek alami yang tidak hidup. Sebagai contoh objek alami yang hidup yaitu ikan, burung dan sebagainya. Sedangkan objek alami yang tidak hidup adalah batu-batuan, kayu dan sebagainya. Objek buatan contohnya, yaitu buatan manusia contoh gedung, mainan dan sebagainya.

Setiap jenis media memiliki karakteristik masing-masing, begitu 
pula dengan media visual tiga dimensi. Nana Sudjana dalam Asrotun (2014: 17) memaparkan karakteristik penggunaan media visual tiga dimensi yaitu sebagai berikut:

1) Praktis dalam penggunaannya

2) Mampu menyajikan teori dan praktik secara terpadu

3) Melibatkan siswa dalam penggunaannya

4) Pesan yang sama dapat disebarkan kepada siswa secara serentak

5) Mengatasi ruang, waktu dan indra.

Tentu saja dalam penggunaan

media ini memerlukan kajian tentang keefektifan dan keefisienan dalam penggunaan dan tujuan yang akan dicapai dalam proses pembelajaran sehingga dapat membantu dan mempermudah kelancaran proses pembelajaran di dalam kelas.

\section{Hasil Belajar Matematika Siswa} SD

Pembelajaran

matematika diharapkan mampu memberikan suatu pemahaman siswa yang terintegrasi, komprehensif dan holistik tentang materi yang telah disajikan. Pemahaman yang dimaksud tidak hanya sekedar memenuhi tuntutan pembelajaran matematika secara substantif saja, namun dapat memberikan manfaat yang berarti kepada siswa.
Kita ketahui bahwa anak usia SD berada pada concrete operational period atau masa operasional konkret yang berada pada usia antara 7-12 tahun. Di mana pada periode ini anak mulai mampu mengonservasi pengetahuan tertentu. "Perilaku kognitif yang tampak pada periode ini ialah kemampuan dalam proses berpikir untuk mengoperasikan kaidah-kaidah logika meskipun masih terikat dengan objek-objek yang bersifat konkret" (Nurihsan dan Agustin, 2011, hlm. 29).

Pembelajaran matematika merupakan suatu proses belajar mengajar yang mengandung dua jenis kegiatan yang tidak dapat terpisahkan antara satu dengan yang lainnya, yaitu belajar dan mengajar. Kedua aspek ini akan berkolaborasi secara terpadu menjadi suatu kegiatan interaksi antara siswa dengan guru, antara siswa dengan siswa, dan siswa dengan lingkungan disaat pembelajaran matematika sedang berlangsung (Nirmala, 2009, hlm. 15). Selanjutnya menurut Bahri dan Zain (2010, hlm. 37) bahwa kegiatan belajar mengajar adalah suatu kondisi yang dengan sengaja diciptakan. Guru yang mengajar dan siswa yang 
belajar. Dari perpaduan kedua unsur manusiawi ini, maka lahirlah interaksi edukatif yang menggunakan media pembelajaran sebagai bahan belajarnya sehingga dapat menimbulkan dan mengembangkan kemampuan belajar siswa.

Sudjana (2009: 22) menyatakan hasil belajar adalah kemampuankemampuan yang dimiliki siswa setelah ia menerima pengalaman belajarnya. Selanjutnya Purwanto dalam Norvelly (2010: 63) menyatakan bahwa hasil belajar adalah perubahan perilaku yang terjadi setelah mengikuti proses belajar mengajar sesuai dengan tujuan pendidikan. Ini berarti dapat juga diartikan suatu konsep yang dapat diserap oleh orang sehingga menghasilkan hal yang baru setelah melakukan rangkaian proses pembelajaran.

Dalam proses pembelajaran matematika, baik guru maupun siswa sama-sama menjadi pelaku terlaksananya tujuan pembelajaran dalam mengembangkan pengetahuannya. Suatu pengetahuan yang baik biasanya tidak diperoleh dengan cara diberikan atau ditransfer dari orang lain saja, melainkan "dibentuk dan dikonstruksi" oleh individu itu sendiri, sehingga siswa tersebut mampu mengembangkan kemampuan intelektualnya.

\section{METODE PENELITIAN}

Jenis penelitian ini adalah quasi eksperimen. Penelitian ini bertujuan untuk mengetahui perbedaan hasil belajar matematika siswa yang memperoleh pembelajaran menggunakan media visual tiga dimensi dengan siswa yang memperoleh pembelajaran dengan media dua dimensi.

Subjek dari penelitian ini adalah siswa kelas IV di SD Muhammadiyah 6 Pekanbaru dengan jumlah siswa kelas IVA sebanyak 24 siswa dan kelas IVB sebanyak 23 siswa. Penelitian ini dilaksanakan selama 3 bulan sebanyak 3 kali perlakuan baik di kelas eksperimen maupun kelas kontrol. Instrumen penelitian ini berupa tes tertulis (tes awal dan tes akhir) yang berjumlah 25 soal yang telah divalidasi.

Adapun teknik pengumpulan data yang digunakan dalam penelitian ini adalah: (1) Pretest. Teknik pengumpulan data berupa tes awal (Pretest) untuk mengetahui 
kemampuan awal siswa di kedua kelas sebelum diberi perlakuan; (2) Perlakuan. Setelah dilakukan pretest maka diberi perlakuan sebanyak tiga kali pertemuan yaitu pembelajaran dengan menggunakan media visual tiga dimensi di kelas ekperimen dan pembelajaran dengan menggunakan media visual dua dimensi di kelas kontrol; (3) Postest. Teknik pengumpulan data berupa tes akhir (postest) untuk mengetahui keterampilan membaca pemahaman siswa kelas ekperimen dan kelas kontrol setelah diberi perlakuan.

Analisis data dalam penelitian ini adalah analisis data hasil tes yang digunakan untuk mengetahui besarnya pengaruh media visual tiga dimensi pada kelas eksperimen dan besarnya peningkatan hasil belajar siswa antara kelas eksperimen dengan kelas kontrol. Teknik analisis data yang digunakan adalah menghitung rata-rata, standar deviasi, varians, melakukan uji normalitas, uji homogenitas, uji perbandingan baik pada skor tes awal maupun tes akhir. Analisis data dilanjutkan dengan perhitungan peningkatan kompetensi yang terjadi sebelum dan sesudah pembelajaran dengan rumus gain ternormalisasi (normalized gain) yang dikembangkan oleh Hake dalam Sundayana (2014), yaitu:

$$
\frac{\text { skor postes - skor pretes }}{\text { skor ideal - skor pretes }}
$$

(Sundayana, 2014: 151)

Tabel 1. Kategori Gain Ternormalisasi

\begin{tabular}{|c|c|}
\hline $\begin{array}{c}\text { Nilai } \\
\text { Ternormalisasi }\end{array}$ & Interpretasi \\
\hline$-1,00 \leq \mathrm{g}<0,00$ & Terjadi penurunan \\
\hline$g=0,00$ & $\begin{array}{c}\text { Tidak terjadi } \\
\text { peningkatan }\end{array}$ \\
\hline $0,00<\mathrm{g}<0,30$ & Rendah \\
\hline $0,30 \leq \mathrm{g}<0,70$ & Sedang \\
\hline $0,70 \leq \mathrm{g} \leq 1,00$ & Tinggi \\
\hline
\end{tabular}

(Sumber: Sundayana, 2014: 151)

Dalam melakukan uji normalitas untuk mengetahui apakah data berdistribusi normal atau tidak yang dilakukan dengan metode uji liliefors. Dihitung dengan menggunakan langkah-langkah berikut (Sundayana, 2014):

1) Menghitung nilai rata-rata dan simpangan baku data.

2) Susunlah data dari yang terkecil sampai data yang terbesar pada tabel.

3) Mengubah nilai $x$ pada nilai $z$ dengan rumus:

$$
Z=\frac{x-\bar{x}}{s}
$$


4) Menghitung luas $z$ dengan menggunakan tabel z

5) Menentukan nilai proporsi data yang lebih kecil atau sama dengan data tersebut.

6) Menghitung selisih luas $z$ dengan nilai proporsi.

7) Menentukan luas maksimum ( $\left.L_{\text {maks }}\right)$ dari langkah $f$.

8) Menentukan luas tabel liliefors $\left(L_{\text {tabel }}\right) ; L_{\text {tabel }}=L_{\alpha}(n-1)$

Kriteria kenormalan: jika $L_{\text {maks }}<$ $L_{\text {tabel }}$ maka data berdistribusi normal.

a. Melakukan uji homogenitas dengan rumus:

$F_{\text {hitung }}=\frac{\text { varians besar }}{\text { varians kecil }}$

(Rostina Sundayana, 2014: 144)

Dengan kriteria pengujian sebagai berikut.

Jika $\mathrm{F}_{\text {hitung }} \geq \mathrm{F}_{\text {tabel }} \rightarrow$ Tidak

homogen

Jika $F_{\text {hitung }} \leq \mathrm{F}_{\text {tabel }} \rightarrow$ Homogen

b. Melakukan uji perbandingan dengan rumus:

$t_{\text {hitung }}=\frac{\overline{x_{1}}-\overline{x_{2}}}{s_{\text {gabungan }} \sqrt{\frac{n_{1}+n_{2}}{n_{1} \cdot n_{2}}}} \quad$ dengan

$\mathrm{dk}=\mathrm{n}_{\mathrm{x}}+\mathrm{n}_{\mathrm{y}}-2$

$s_{\text {gabungan }}=\sqrt{\frac{\left(n_{1}-1\right) s_{1}^{2}+\left(n_{2}-1\right) s_{2}^{2}}{n_{1}+n_{2}-2}}$

(Rostina Sundayana, 2014: 146)

\section{HASIL DAN PEMBAHASAN}

Hasil penelitian ini dilakukan berdasarkan analisis dan temuantemuan di lapangan. Berdasarkan analisis data dihasilkan beberapa temuan beserta pembahasannya diantaranya adalah hasil tes awal, hasil tes akhir, besarnya pengaruh pada kelas eksprimen, dan peningkatan skor kemampuan siswa pada kelas kontrol dan kelas eksperimen..

Pada tes awal rata-rata kelas eksperimen 54,96 dengan standar deviasi 13,55 dan varians 183,60. Sedangkan rata-rata tes awal kelas kontrol 55,67 dengan standar deviasi 13,85 dan varians 191,82. Selanjutnya, dilakukan uji normalitas menggunakan uji liliefors dan uji homogenitas menggunakan uji fisher sebagai uji prasyarat dalam menentukan uji perbandingan yang tepat untuk digunakan. Hasil uji lilliefors skor tes awal menunjukkan bahwa dengan taraf signifikan $\alpha=$ 0,05, skor $L_{\text {maks }}$ kemampuan awal siswa kelas eksperimen dan kelas kontrol memenuhi kriteria $L_{\text {maks }}<L_{\text {tabel }}$ yaitu untuk kelas eksperimen 0,085 < 0,1840 dan kelas kontrol 0,175< 0,1798. Hal ini menunjukkan bahwa 
skor tes awal siswa kelas eksperimen dan kelas kontrol berdistribusi normal. Langkah selanjutnya adalah melakukan uji homogenitas varians skor tes awal kelas eksperimen dan kelas kontrol. Dengan menggunakan taraf signifikan $\alpha=0,05$, hasil uji homogenitas menunjukkan bahwa $F_{\text {hitung }}<F_{\text {tabel }}$ atau 1,045 $<2,03$. Hal ini berarti bahwa varians kelas eksperimen dan kelas kontrol bersifat homogen dan dilanjutkan dengan uji t.

Tabel 2. Hasil Uji t Tes awal

\begin{tabular}{|c|c|c|c|c|c|c|}
\hline \multirow[b]{2}{*}{ Kelas } & \multicolumn{5}{|c|}{ Uji t } & \multirow{2}{*}{$\begin{array}{l}\text { Keput } \\
\text { usan }\end{array}$} \\
\hline & $\overline{\mathrm{X}}$ & $S^{2}$ & $\begin{array}{l}\mathrm{S}_{\text {gab }} \\
\text { ungan }\end{array}$ & $\begin{array}{l}\mathrm{t}_{\text {hitu }} \\
\mathrm{ng}\end{array}$ & $\begin{array}{l}t_{\text {tab }} \\
\text { el }\end{array}$ & \\
\hline $\begin{array}{l}\text { Ekspe } \\
\text { rimen }\end{array}$ & $\begin{array}{l}54, \\
96\end{array}$ & $\begin{array}{l}183 \\
, 60\end{array}$ & & & & $\begin{array}{l}\text { Tidak } \\
\text { terda } \\
\text { pat }\end{array}$ \\
\hline & & & 13,7 & 0,1 & 2,0 & perbe \\
\hline Kontro & 55 & 191 & 0 & 79 & 14 & $\begin{array}{l}\text { daan } \\
\text { yang }\end{array}$ \\
\hline I & 67 & ,82 & & & & $\begin{array}{l}\text { signifi } \\
\text { kan }\end{array}$ \\
\hline
\end{tabular}

(Sumber: Olahan Peneliti, 2017)

Berdasarkan tebel hasil uji t di atas kelas eksperimen dengan kelas kontrol memiliki $t_{\text {hitung }} 0,179$ dan $t_{\text {tabel }}$ 2,014, sehingga kemampuan awal siswa kelas eksperimen dan kelas kontrol memenuhi kriteria $t_{\text {hitung }}<t_{\text {tabel }}$ yaitu $0,179<2,014$. Hal ini menunjukkan bahwa Ho diterima berarti tidak terdapat perbedaan yang signifikan antara siswa kelas eksperimen dengan kelas kontrol pada tes awal. Dilihat dari hasil uji perbedaan rata-rata tersebut, siswa dari kelas eksperimen dan kelas kontrol memiliki kemampuan awal yang sama, atau tidak terdapat perbedaan yang signifikan pada kemampuan siswa sebelum mendapatkan perlakuan.

Setelah mengalami proses pembelajaran sebanyak tiga kali pertemuan di kelas eksperimen dan tiga kali pertemuan di kelas kontrol, selanjutnya siswa dari kelas eksperimen dan kelas kontrol diberikan tes akhir. Pemberian tes akhir bertujuan untuk mengetahui besarnya pengaruh dan peningkatan kemampuan siswa setelah diberikan perlakuan. Hasil analisis terhadap skor tes akhir, diketahui bahwa siswa yang belajar menggunakan media visual tiga dimensi di kelas eksperimen memiliki rata-rata 79,13 tes akhir sebesar dengan standar deviasi 10,44, sedangkan kelas kontrol memiliki rata-rata tes akhir sebesar 64,33 dengan standar deviasi 11,73 .

Berdasarkan perbedaan ratarata tes akhir tersebut dapat dilihat bahwa terdapat perbedaan kemampuan yang signifikan antara 
siswa yang belajar menggunakan menggunakan media visual tiga dimensi dengan siswa yang belajar menggunakan media visual dua dimensi Perbedaan ini didasarkan setelah adanya uji perbedaan antara kelas eksperimen dengan kelas kontrol dengan menggunakan uji-t.

Tabel 3. Hasil Uji-t Tes Akhir

\begin{tabular}{|c|c|c|c|c|c|c|}
\hline \multirow[b]{2}{*}{ Kelas } & \multicolumn{5}{|c|}{ Uji t } & \multirow{2}{*}{$\begin{array}{l}\text { Keput } \\
\text { usan }\end{array}$} \\
\hline & $\overline{\mathrm{X}}$ & $S^{2}$ & $\begin{array}{l}\mathrm{S}_{\text {gabu }} \\
\text { ngan }\end{array}$ & $\begin{array}{l}t_{\text {hitu }} \\
n g\end{array}$ & $t_{\text {tabe }}$ & \\
\hline $\begin{array}{l}\text { Eksperi } \\
\text { men }\end{array}$ & $\begin{array}{l}79 \\
13\end{array}$ & $\begin{array}{l}108, \\
99\end{array}$ & 11,1 & 4, & 2,0 & $\begin{array}{l}\text { terdap } \\
\text { at } \\
\text { perbed }\end{array}$ \\
\hline Kontrol & $\begin{array}{l}64 \\
33\end{array}$ & $\begin{array}{l}137 \\
59\end{array}$ & 2 & 59 & 14 & $\begin{array}{l}\text { aan } \\
\text { yang } \\
\text { signifik } \\
\text { an }\end{array}$ \\
\hline
\end{tabular}

(Sumber: Olahan Peneliti, 2017)

Dari tabel perhitungan uji t di atas diperoleh skor akhir siswa kelas eksperimen dan kelas kontrol memenuhi kriteria $t_{\text {hitung }}>t_{\text {tabel }}$ yaitu 4,59 >2,014yang menunjukkan bahwa $\mathrm{Ha}$ diterima dan Ho ditolak, yang artinya terdapat perbedaan kemampuan siswa yang signifikan antara siswa kelas eksperimen dengan kelas kontrol pada tes akhir. Setelah dilakukan tes awal (pretest) dan tes akhir (postest), untuk mengetahui peningkatan skor keterampilan membaca pemahaman siswa maka dilakukanlah analisis peningkatan skor sebelum dan sesudah perlakuan yang dihitung dengan uji gain ternormalisasi (normalized gain).

Tabel 4. Statistik Deskriptif Skor Indeks Gain Kelas Kontrol dan Kelas Eksperimen.

\begin{tabular}{lllllll}
\hline Kelas & $\mathrm{N}$ & $\overline{\mathrm{X}}$ & $\begin{array}{l}\text { Standar } \\
\text { Deviasi }\end{array}$ & $\begin{array}{l}\mathrm{X} \\
\mathrm{Max}\end{array}$ & $\begin{array}{l}\mathrm{X} \\
\text { Min }\end{array}$ & $\begin{array}{l}\text { Krite } \\
\text { ria }\end{array}$ \\
\hline Eksperimen & 23 & 0,54 & 0,17 & 0,80 & 0,11 & $\begin{array}{l}\text { Sed } \\
\text { ang }\end{array}$ \\
Kontrol & 24 & 0,05 & 0,16 & 0,53 & 0,00 & $\begin{array}{l}\text { Ren } \\
\text { dah }\end{array}$ \\
\hline
\end{tabular}

(Sumber: Olahan Peneliti, 2017)

Berdasarkan tabel di atas diketahui bahwa rata-rata peningkatan hasil belajar kelas eksperimen 0,54 (kategori sedang) dan kelas kontrol 0,05 (kategori rendah). Selanjutnya melakukan uji normalitas data dengan menggunakan uji liliefors. Dari hasil uji lilliefors gain dengan taraf signifikan $\alpha$ $=0,05$ diperoleh bahwa $L_{\text {maks }}<L_{\text {tabel }}$ yaitu, untuk kelas eksperimen 0,095 < 0,1840 dan kelas kontrol 0,222 > 0,1798 . Hal ini menunjukkan bahwa skor gain siswa kelas eksperimen berdistribusi normal dan kelas kontrol berdistribusi tidak normal. Oleh karena itu, maka untuk menguji rerata kelas eksperimen dan kelas kontrol menggunakan uji mann whitney. 
Tabel 5. Hasil Uji Mann Whitney Gain menggunakan media visual tiga Kelas Eksperimen dan Kelas Kontrol

\begin{tabular}{|c|c|c|c|c|c|}
\hline \multirow[b]{2}{*}{ Kelas } & \multicolumn{4}{|c|}{ Uji Mann Whitney } & \multirow[t]{2}{*}{ Keputusan } \\
\hline & gain & $\begin{array}{l}\text { Kateg } \\
\text { ori }\end{array}$ & $Z_{\text {hitun }}$ & $Z_{\text {tabel }}$ & \\
\hline Ekspe & 0,54 & Sedan & & & Terdapat \\
\hline rimen & & g & 5,39 & & perbedaan \\
\hline $\begin{array}{l}\text { Kontro } \\
\text { I }\end{array}$ & 0,05 & $\begin{array}{l}\text { Renda } \\
\mathrm{h}\end{array}$ & 5 & & $\begin{array}{l}\text { an yang } \\
\text { signifikan }\end{array}$ \\
\hline
\end{tabular}

(Sumber: Olahan Peneliti, 2017)

Berdasarkan tabel hasil uji mann whitney di atas, ditemukan bahwa peningkatan hasil belajar kedua kelas memiliki perbedaan yang signifikan. Perbedaan ini didasarkan dengan adanya uji perbedaan indeks gain antara kelas eksperimen dan kelas kontrol dengan menggunakan uji Mann Whitney. Dari perhitungan uji Mann Whitney diperoleh $\quad Z_{\text {hitung }}=$ 5,395 dan $z_{\text {tabel }}=1,96$. hasil uji-t tersebut menunjukkan bahwa terdapat perbedaan yang signifikan antara siswa yang belajar dengan menggunakan media visual tiga dimensi dengan siswa yang belajar dengan media visual dua dimensi.

Sebelum

dilakukan pembelajaran dengan menggunakan media visual tiga dimensi aktivitas dapat dikatakan hanya mendengarkan penjelasan dari guru. Hal ini berbeda dengan pembelajaran yang dimensi, dimana siswa secara aktif untuk menemukan, bertanya, sehingga siswa dapat mengingat materi dalam waktu jangka panjang. Hal ini sejalan dengan karakteristik dari media visual tiga dimensi menurut Nana Sudjana dalam Asrotun (2014: 17) yang salah satunya yaitu dengan melibatkan siswa

dalam penggunaannya hal ini terlihat dari hasil uji perbedaan rata-rata tes awal dimana antara kelas eksperimen dengan kelas kontrol tidak memiliki perbedaan rata-rata skor secara signifikan.

Setelah mengalami proses pembelajaran sebanyak tiga kali pertemuan di kelas eksperimen dan tiga kali pertemuan di kelas kontrol, selanjutnya siswa dari kelas eksperimen dan kelas kontrol diberikan tes akhir. Pemberian tes akhir bertujuan untuk mengetahui besarnya pengaruh dan peningkatan kemampuan siswa setelah diberikan perlakuan. Hasil analisis terhadap skor tes akhir, diketahui bahwa terdapat perbedaan peningkatan ratarata antara siswa kelas eksperimen dan kelas kontrol. Hal ini didukung oleh hasil uji $t$ yang menyatakan 
bahwa terdapat perbedaan yang signifikan siswa yang belajar menggunakan media visual tiga dimensi dengan siswa yang belajar menggunakan media visual dua dimensi. Selain terdapat perbedaan rata-rata, juga terdapat perbedaan peningkatan antara siswa yang belajar menggunakan media visual tiga dimensi dengan siswa yang belajar menggunakan media visual dua dimensi. Hal tersebut terlihat pada hasil uji mann whitney gain bahwa terdapat perbedaan yang signifikan antara siswa yang belajar menggunakan media visual tiga dimensi dengan siswa yang belajar menggunakan media visual dua dimensi.

Adanya peningkatan hasil belajar siswa pada siswa kelas eksperimen yang lebih tinggi dari pada kelas kontrol menunjukkan bahwa pembelajaran dengan menggunakan media visual tiga dimensi dapat meningkatkan hasil belajar siswa karena pembelajaran dengan menggunakan media visual tiga dimensi telah mampu merubah pembelajaran biasa selama ini yang berpusat pada guru menjadi pembelajaran yang lebih baik dengan menitikberatkan pada keaktifan siswa.
Hal tersebut dapat dilihat dari hasil pengamatan yang dilakukan selama proses pembelajaran yaitu kelas eksperimen lebih aktif jika dibandingkan dengan kelas kontrol. Hal itu disebabkan pada pembelajaran dengan media visual tiga dimensi siswa dapat memahami lebih dalam materi sifat bangun ruang balok dan kubus sesuai dengan kelebihan dari media visual tiga dimensi menurut Moedjiono dalam Daryanto (2015: 29), yaitu: 1) memberikan pengalaman secara langsung; 2) menyajikan secara konkrit dan mengjindari verbalisme; 3) dapat menunjukkan objek secara utuh, baik kontruksi maupun cara kerjanya; 4) dapat memperlihatkan struktur organisasi secara jelas; 5) dapat menunjukkan alur suatu proses secara jelas.

\section{E. PENUTUP}

Berdasarkan hasil analisis data dan temuan yang diperoleh dalam penelitian dapat disimpulkan bahwa terdapat perbedaan peningkatan hasil belajar yang signifikan antara kelas yang menggunakan media visual tiga dimensi dengan kelas yang menggunakan media visual dua dimensi dengan taraf signifikan 0,05. 
Hal ini dibuktikan dengan terdapatnya peningkatan hasil belajar matematika pada kelas eksperimen dari rata-rata tes awal (pretest) 54,96 menjadi 79,13 pada tes akhir (postes) dengn ratarata peningkatan (gain) 0,54 (termasuk kategori sedang). Sedangkan kelas kontrol memiliki peningkatan rata-rata tes awal (pretest) dari 55,67 menjadi 64,33 pada tes akhir (postes) dengan ratarata peningkatan (gain) 0,05 (termasuk kategori rendah). Hal itu menunjukkan bahwa terdapat perbedaan yang signifikan antara kelas yang menggunakan media visual tiga dimensi (eksperimen) dengan kelas yang menggunakan media visual dua dimensi (kontrol).

Adapun saran dalam penelitian ini adalah sebagai berikut: 1) bagi guru di sekolah dasar untuk meningkatkan hasil belajar matematika khusus pada materi sifat bangun ruang sederhana sebaiknya menggunakan media visual tiga dimensi. Namun, akan lebih baik jika guru menyediakan media dengan bermacam warna seperti merah, biru, kuning serta dengan jaring-jaring yang lebih beragam. 2) bagi guru kelas dalam meningkatkan hasil belajar diharapkan untuk lebih sering menggunakan media yang bervariasi agar dapat meningkatkan pemahaman siswa terhadap materi yang diajarkan. 3) kepada peneliti selanjutnya agar dapat meneliti/ mengembangkan penggunaan media visual tiga dimensi dengan tampilan yang lebih baik kedepannya.

\section{DAFTAR PUSTAKA}

Arsyad, A. (2016). Media Pembelajaran. Jakarta: PT Raja Grafindo Persada.

Asrotun. (2014). Penggunaan Media Tiga Dimensi untuk Meningkatkan Hasil Belajar Matematika Siswa. (Skripsi) Fakultas Tarbiyah dan Keguruan Universitas Islam Negeri, Jakarta.

Bahri, S \& Zain, A. (2010). Strategi Belajar Mengajar. Jakarta: Rineka Cipta.

Fendrik, M. (2015). Analisis Kemampuan Habits of Mind Matematis Siswa Kelas $V$ Sekolah Dasar. Jurnal Sekolah Dasar: Kajian Pengembangan Pendidikan 2 (2): 80-91. PGSD FKIP Universitas Sriwijaya. Palembang. 
Mumtahanah, N. (2014). Penggunaan Media Visual Dalam Pembelajaran PAI. Al-Hikmah: Jurnal Studi Keislaman 4 (1): 91 104.

Nirmala. (2009). Pembelajaran Matematika dengan Pendekatan Habits of Mind untuk Meningkatkan Kemampuan Pemahaman dan Komunikasi Matematik Siswa Sekolah Dasar. (Tesis) Sekolah Pascasarjana Universitas Pendidikan Indonesia, Bandung.

Norvelly. (2010). Pengaruh

Penggunaan Media Flash Card Terhadap Motivasi dan Hasil Belajar Siswa Kelas IV SDN 003 Peranap. (Skripsi). FKIP Universitas Riau, Pekanbaru.

Nurihsan, J \& Agustin, M. (2011). Dinamika Perkembangan Anak dan Remaja: Tinjauan Psikologi, Pendidikan, dan Bimbingan. Bandung: Refika Aditama.
Rima, E. (2016). Ragam Media Pembelajaran.Yogyakarta: Kata Pena.

Sanjaya, W. (2011). Perencanaan dan Desain Sistem Pembelajaran. Jakarta: Kencana.

Sudjana, Nana. (2009). Penilaian Hasil Proses Belajar Mengajar. Bandung : PT. Remaja Rosda karya.

Sundayana, R. (2014). Statistika Penelitian Pendidikan. Bandung: Alfabeta.

Sundayana, R. (2015). Media dan Alat Peraga dalam Pembelajaran Matematika. Bandung: Alfabeta.

Susilana, R dan Riyana, C. (2009). Media Pembelajaran. Bandung: CV Wacana Prima.

Undang-Undang Republik Indonesia tentang Sistem Pendidikan Nasional Nomor 20 Tahun 2003. 